\title{
Perspective
}

\section{Antibody therapeutics targeting ion channels: are we there yet?}

\author{
Han SUN, Min LI* \\ Department of Neuroscience, High Throughput Biology Center and Johns Hopkins Ion Channel Center (JHICC), School of Medicine, \\ Johns Hopkins University, Baltimore, MD 21205, USA
}

\begin{abstract}
The combination of technological advances, genomic sequences and market success is catalyzing rapid development of antibodybased therapeutics. Cell surface receptors and ion channel proteins are well known drug targets, but the latter has seen less success. The availability of crystal structures, better understanding of gating biophysics and validation of physiological roles now form an excellent foundation to pursue antibody-based therapeutics targeting ion channels to treat a variety of diseases.
\end{abstract}

Keywords: ion channel; antibody; autoimmune neurological disorder; channelopathy; protein-based therapeutics

Acta Pharmacologica Sinica (2013) 34: 199-204; doi: 10.1038/aps.2012.202

\section{Introduction}

Ion channels are a large family of membrane proteins that function by allowing ionic passage across cellular membranes. They are present in all cell types and play critical roles in a variety of biological processes. Among more than 429 annotated ion channel genes, many are important and validated therapeutic targets. Antibodies for ion channels are effective tools and widely used in various experimental settings. However, rarely have they been used to perturb ion channel function. So far no antibody-based drug on the market is targeted to an ion channel.

Epitopes on ion channels accessible by active antibodies Patients with autoimmune disorders develop self-reacting antibodies. Some are autoantibodies against ion channels. Their roles in pathogenesis are implicated by correlation between antibody titer and severity of disease, effectiveness of plasma exchange, or immunosuppressive therapy. For example, paraneoplastic channelopathies are autoimmune neurological disorders that co-exist with tumors and tumor antigens are indicated as the trigger for autoantibody generation. In these instances, autoantibodies are utilized as diagnostic or prognostic markers for both neurological diseases as well as cancer (see review ${ }^{[1]}$ ). Indeed, many known autoimmune channelopathies involve antibodies that target voltage-gated

\footnotetext{
* To whom correspondence should be addressed.

E-mail minli@jhmi.edu

Received 2012-12-28 Accepted 2013-01-01
}

ion channels. Mechanistic studies reveal that these antibodies can cause functional changes in ion channels that lead to clinical phenotypes. For example, Lambert-Eaton Myasthenic Syndrome (LEMS) is a disorder of neuromuscular transmission in which antibodies are directed to presynaptic voltage-gated calcium channels resulting in muscle weakness. Experimental evidence showed that bivalent antibodies were required for the overall reduction of acetylcholine release, supporting the notion that antibody-mediated cross-linking and subsequent internalization of channel protein leads to reduction in calcium influx ${ }^{[2]}$. Further investigation indicated that the LEMS patient-derived IgGs were capable of inhibiting P- and Q-type calcium currents specifically ${ }^{[3]}$.

Antibodies against voltage-gated potassium channels contribute to a broader range of autoimmune disorders, involving both the central nervous system and peripheral nervous system. In some patients with acquired neuromyotonia (NMT), also known as Isaac's syndrome, antibodies against voltagegated potassium channels prevent membrane re-polarization, increase acetylcholine release, and prolong action potentials. The excess release of acetylcholine often leads to muscle twitching, cramps, stiffness, and abnormal muscle contraction and relaxation. Peripheral nerve hyper-excitability sometimes co-exists with effects in the central nervous system, including seizures, sleep disturbance, and behavioral changes. Treatments with patient antibodies led to a marked increase in compound action potential current and repetitive firing in isolated dorsal root ganglia (DRGs) similar to those observed with $\mathrm{K}_{\mathrm{v}}$ channel blockers, such as aminopyridines ${ }^{[4]}$. Experimental evi- 
dence suggested that these antibodies act by inducing channel internalization ${ }^{[5]}$. Besides NMT, voltage-gated potassium channel antibodies have been detected in patients with crampfasciculation syndrome, limbic encephalitis (LE) and Morvan's syndrome (MoS). Immunohistochemical studies provided evidence that these autoantibodies display subtype-specificity. NMT and MoS antibodies bind preferentially to $\mathrm{K}_{\mathrm{v}} 1.2$ and $\mathrm{K}_{\mathrm{v}} 1.6$, whereas LE antibodies have a preference for $\mathrm{K}_{\mathrm{v}} 1.1$. Difference in target specificity serves as one explanation for various clinical manifestations in these disorders ${ }^{[6]}$.

Besides paraneoplastic channelopathies, antibodies targeting ion channels have been associated with many other disorders including multiple sclerosis (MS). MS is the most common chronic inflammatory disease of the central nervous system. Although some patients are responsive to plasma exchange or B cell depletion by monoclonal antibodies, therapeutic outcome is often unpredictable due to unknown pathogenesis and clinical heterogeneity. Recently, Kir4.1 has been found to be the immune target in MS. Serum antibodies recognizing the first extracellular loop of Kir4.1 were detected in $~ 50 \%$ MS patients compared to less than $1 \%$ of patients with other neurologic diseases. Injection of serum IgG resulted in a significant loss of channel expression and altered expression of glial protein along with complement activation in mice. It is likely that in addition to triggering immune responses, Kir4.1 antibodies could interfere with channel function leading to impaired axon myelination and tissue damage ${ }^{[7]}$.

\section{Development of active antibodies}

As early as three decades ago, active antibodies were generated and noted for their utility in functional studies of voltage-gated ion channels. Monoclonal antibodies (mAbs) were raised against membrane fragments from eel electroplax enriched for voltage-gated sodium channel ${ }^{[8,9]}$. Among these antibodies, three exhibited an effect on channel activity. SC-66-5 and SC-72-14 attenuated the action potential in rat nerve fibers by inhibiting depolarization and prolonging repolarization ${ }^{[8]}$. In follow-up studies, SC-72-14 was shown to alter the voltage-dependence of channel inactivation and inhibit sodium current ${ }^{[10]}$. When tested on canine cardiac fibers, SC-72-14 reduced $V_{\max }$ and membrane responsiveness ${ }^{[11]}$. Another antibody, SC-72-38, enhanced the excitability of rat muscle cells by changing the voltage-dependence of sodium channel activation and inactivation. The observed changes were similar to those induced by Tityus serrulatus toxin $Y$ (TiTXY), and the binding of SC-72-38 and TiTXY was mutually exclusive $^{[12]}$. In another study, a mAb against dihydropyridine (DHP)-binding complex in rabbit muscle transverse tubules was generated and it suppressed the slow calcium current in a mouse muscle cell line. It also cross-reacted with sodium channel, shifting the voltage of activation threshold to a more positive value and slowing the rate of inactivation ${ }^{[13,14]}$.

To gain higher preference for subtype selectivity and harness the benefits of human genome sequence data, instead of injecting homogenized membrane fragments, synthetic peptides or recombinant proteins corresponding to a specific region in the channel are used to generate antibodies. Different regions in ion channels have been explored in rational target design for intended activity and specificity. For instance, regions in close proximity to the pore are of particular interest, since perturbation through antibody binding is likely to affect conductance. This strategy is supported by several studies. An antibody targeted at a region of the voltage-dependent calcium channel $\alpha_{1 D}$ subunit C-terminal to the pore-forming loop effectively reduced $30 \%-50 \%$ of native L-type calcium currents in DRG neurons and cardiac myocytes under depolarizing conditions ${ }^{[15]}$. Alternatively, antibodies can be generated against the small extracellular loop $\mathrm{N}$-terminal to the poreforming region. This region is extracellularly accessible and in many cases it displays considerable sequence variation, and thus may lead to the development of highly specific antibodies. This strategy, now known as E3 targeting (named after the third extracellular loop), was first examined in studies of voltage-gated potassium channels. Polyclonal anti-peptide antibodies that specifically recognized the E3 domain of $\mathrm{K}_{\mathrm{v}} 1.2$ or $\mathrm{K}_{v} 3.1$ inhibited whole cell currents by more than $70 \%$ in neuronal cells with an $\mathrm{IC}_{50}$ value close to $60 \mathrm{nmol} / \mathrm{L}$. Moreover, $\mathrm{K}_{\mathrm{v}} 1.2$ antibody inhibited the binding of a-dendrotoxin, which is known to interact with $\mathrm{K}_{\mathrm{v}} 1.2$ near pore region on the extracellular side ${ }^{[16]}$. Over the years, E3 targeting has been extended to investigation of several voltage-gated cation channels. For example, E3-targeted antibodies against $\mathrm{Na}_{\mathrm{v}} 1.5$ and TRPC5 inhibited whole cell currents up to $50 \%-60 \%$ in cells transfected with corresponding channels ${ }^{[17]}$. An anti- $\mathrm{K}_{\mathrm{v}} 1.2$ antibody was able to restore consciousness of animals during anesthesia following thalamic microinfusion ${ }^{[18]}$. In a recent study, a polyclonal antibody was raised against the E3 domain in $\mathrm{P} / \mathrm{Q}$-type voltage-gated calcium channels. It effectively inhibited the function of N-type and P/Q-type calcium channels in cerebellar granule cells. Antibody binding abolished the effect of $\omega$-conotoxin-GVIA which binds near to the pore. But it had no effect on $\omega$-agatoxin-IVA that acts on a distal gating modality. When tested at neuromuscular junctions, this antibody attenuated excitatory postsynaptic currents. Moreover, cerebellum infusion caused cerebellar ataxia in mice, establishing a link between anti-voltage-gated calcium channel antibodies and pathogenesis ${ }^{[19]}$. Besides regulating neural excitability, some E3-targeted antibodies could modulate store-operated or agonist-evoked $\mathrm{Ca}^{2+}$ entry ${ }^{[20-25]}$, oligodendrocyte proliferation and migration ${ }^{[26]}$, and tumor growth ${ }^{[27,28]}$.

Channel regions that are not in the immediate vicinity of pore-forming region can be equally useful as active antibody targets. A polyclonal antibody directed to the voltage sensor of internal repeat I in sodium channel shifted the voltage dependence of fast current inactivation to a more negative value in cultured DRG neurons ${ }^{[29]}$. Moreover, it attenuated the action potential amplitude of rat sciatic nerves. Its binding to rat brain synaptosomes was enhanced by depolarization, suggesting a depolarization-induced conformational change that made the epitope more accessible to the antibody ${ }^{[30]}$. NESOpAb, an antibody directed to the second extracellular loop in $\mathrm{Na}_{\mathrm{v}} 1.5$ domain I, inhibited sodium currents up to $60 \%$ 
with an $\mathrm{IC}_{50}$ value of less than $25 \mathrm{nmol} / \mathrm{L}$. It exhibited exquisite selectivity, distinguishing neonatal and adult splice variants which differ by seven amino acids only ${ }^{[31]}$. These studies suggest that ion channels possess many functional sites accessible to specific modulation by antibodies.

\section{Active antibodies from bench to bedside}

Antibodies constitute the fastest growing class of therapeutic agents. Antibody-based therapy has been well established to treat cancer, autoimmune and inflammatory diseases ${ }^{[32,33]}$. Although experimental evidences show that active antibodies can be utilized as research tools to modulate ion channel functions, their therapeutic application awaits further development. Despite experimental data, appropriate in vivo models need to be established to validate and characterize the functions of active antibodies in a defined biological context. Also, many active antibodies reported so far are polyclonal, which are usually not suited for therapeutic purposes. Generation of effective monoclonal antibodies is therefore essential for eventual clinical use. In addition, the structure and function of antibodies require fine tailoring to improve their pharmacological properties and safety. Various strategies and approaches have been developed for this purpose. Recombinant antibody fragments were created to ensure delivery across blood brain barrier (BBB) to target antigens in the brain ${ }^{[34-36]}$. New technologies are becoming more effective to enable antibodies to penetrate $\mathrm{BBB}^{[37]}$, including recent antibodies targeting betasecretase (BACE1) for treating Alzheimer's disease ${ }^{[38,39]}$. Effector functions and plasma half-life of antibodies can be modified via engineering to meet different clinical requirements. Generation of humanized or completely human monoclonal antibodies with enhanced efficacy and safety is achievable via rational design and high throughput screens ${ }^{[40,41]}$. Although numerous challenges remain for applying active antibodies to treat human diseases, knowledge gained through ion channel active antibody research, and the availability of existing and emerging technologies to improve antibody performance will pave the way for development of future therapeutics.

\section{Perspective}

Antibodies recognizing ion channels, whether they have been generated intentionally by artificial immunization or unintentionally as results of autoimmune diseases, are effective in modulation of ion channel activity. The mechanisms of action include direct block of ion permeation pathway, modulation of ion channel gating, and internalization and degradation upon surface clustering (Table 1). The feasibility of developing active antibodies targeting ion channels combined with major advances in antibody technologies over the last decade promises that more effective antibodies may be available in the coming years. Their applications are likely to impact the development of therapeutics for a variety of diseases in which ion channels are validated targets.

\section{Acknowledgements}

We thank members of the Li laboratory for valuable discus- sions, reviewers for helpful comments, and Alison NEAL for editorial assistance. This work is supported by grants to ML from the National Institutes of Health (GM078579, MH084691) and Maryland Stem Cell Research Foundation (2010-MSCRFE0164-00).

\section{References}

1 Vernino S. Autoimmune and paraneoplastic channelopathies. Neurotherapeutics 2007; 4: 305-14.

2 Vincent A, Lang B, Newsom-Davis J. Autoimmunity to the voltagegated calcium channel underlies the Lambert-Eaton myasthenic syndrome, a paraneoplastic disorder. Trends Neurosci 1989; 12: 496-502.

3 Pinto A, Gillard S, Moss F, Whyte K, Brust P, Williams M, et al. Human autoantibodies specific for the $\alpha 1 \mathrm{~A}$ calcium channel subunit reduce both P-type and Q-type calcium currents in cerebellar neurons. Proc Natl Acad Sci U S A 1998; 95: 8328-33.

4 Shillito P, Molenaar PC, Vincent A, Leys K, Zheng W, van den Berg RJ, et al. Acquired neuromyotonia: Evidence for autoantibodies directed against $\mathrm{K}^{+}$channels of peripheral nerves. Ann Neurol 1995; 38 : 714-22.

5 Tomimitsu H, Arimura K, Nagado T, Watanabe O, Otsuka R, Kurono A, et al. Mechanism of action of voltage-gated $\mathrm{K}^{+}$channel antibodies in acquired neuromyotonia. Ann Neurol 2004; 56: 440-4.

6 Kleopa KA, Elman LB, Lang B, Vincent A, Scherer SS. Neuromyotonia and limbic encephalitis sera target mature Shaker-type $\mathrm{K}^{+}$channels: subunit specificity correlates with clinical manifestations. Brain 2006; 129: $1570-84$.

7 Srivastava R, Aslam M, Kalluri SR, Schirmer L, Buck D, Tackenberg B, et al. Potassium channel KIR4.1 as an immune target in multiple sclerosis. N Engl J Med 2012; 367: 115-23.

8 Meiri H, Zeitoun I, Grunhagen HH, Lev-Ram V, Eshhar Z, Schlessinger J. Monoclonal antibodies associated with sodium channel block nerve impulse and stain nodes of ranvier. Brain Res 1984; 310: 168-73.

9 Moore HP, Fritz LC, Raftery MA, Brockes JP. Isolation and characterization of a monoclonal antibody against the saxitoxin-binding component from the electric organ of the eel Electrophorus electricus. Proc Natl Acad Sci U S A 1982; 79: 1673-77.

10 Meiri H, Goren E, Bergmann H, Zeitoun I, Rosenthal Y, Palti Y. Specific modulation of sodium channels in mammalian nerve by monoclonal antibodies. Proc Natl Acad Sci U S A 1986; 83: 8385-9.

11 Morikawa Y, Meiri H, Spinelli W, Rosen M, Robinson R. Modification of Vmax of canine cardiac Purkinje fibers and of the effects of lidocaine by SC-72-14. Circ Res 1985; 57: 354-61.

12 Barhanin J, Meiri H, Romey G, Pauron D, Lazdunski M. A monoclonal immunotoxin acting on the $\mathrm{Na}^{+}$channel, with properties similar to those of a scorpion toxin. Proc Natl Acad Sci U S A 1985; 82: 1842-6.

13 Morton ME, Froehner SC. Monoclonal antibody identifies a 200-kDa subunit of the dihydropyridine-sensitive calcium channel. J Biol Chem 1987; 262: 11904-7.

14 Morton ME, Caffrey JM, Brown AM, Froehner SC. Monoclonal antibody to the alpha 1-subunit of the dihydropyridine-binding complex inhibits calcium currents in BC3H1 myocytes. J Biol Chem 1988; 263: 613-6.

15 Wyatt CN, Campbell V, Brodbeck J, Brice NL, Page KM, Berrow NS, et al. Voltage-dependent binding and calcium channel current inhibition by an anti-alpha 1D subunit antibody in rat dorsal root ganglion neurones and guinea-pig myocytes. J Physio 1997; 502: 307-19.

16 Zhou BY, Ma W, Huang XY. Specific antibodies to the external vestibule of voltage-gated potassium channels block current. J Gen 
Table 1. Summary of active antibodies for voltage-sensitive ion channels.

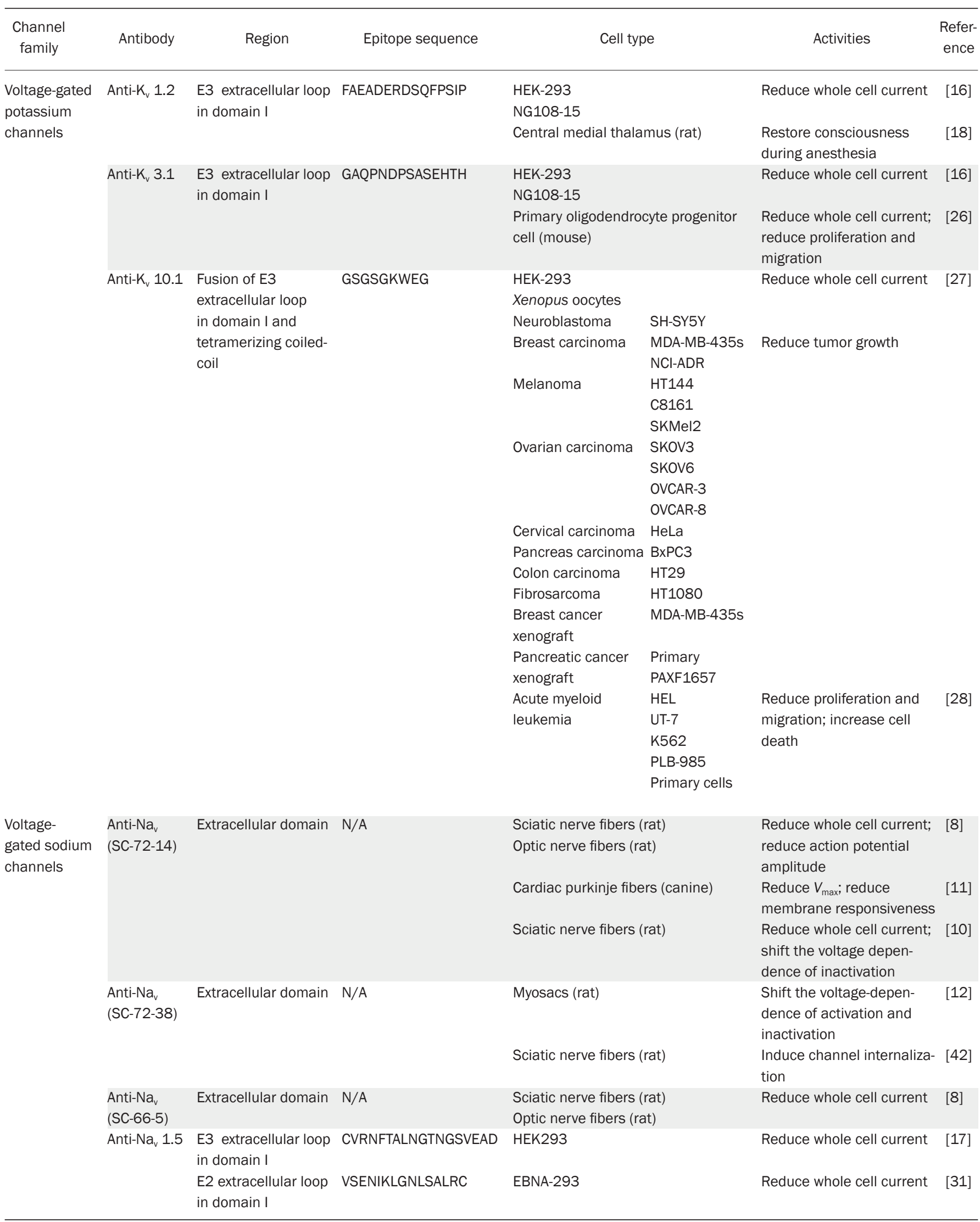




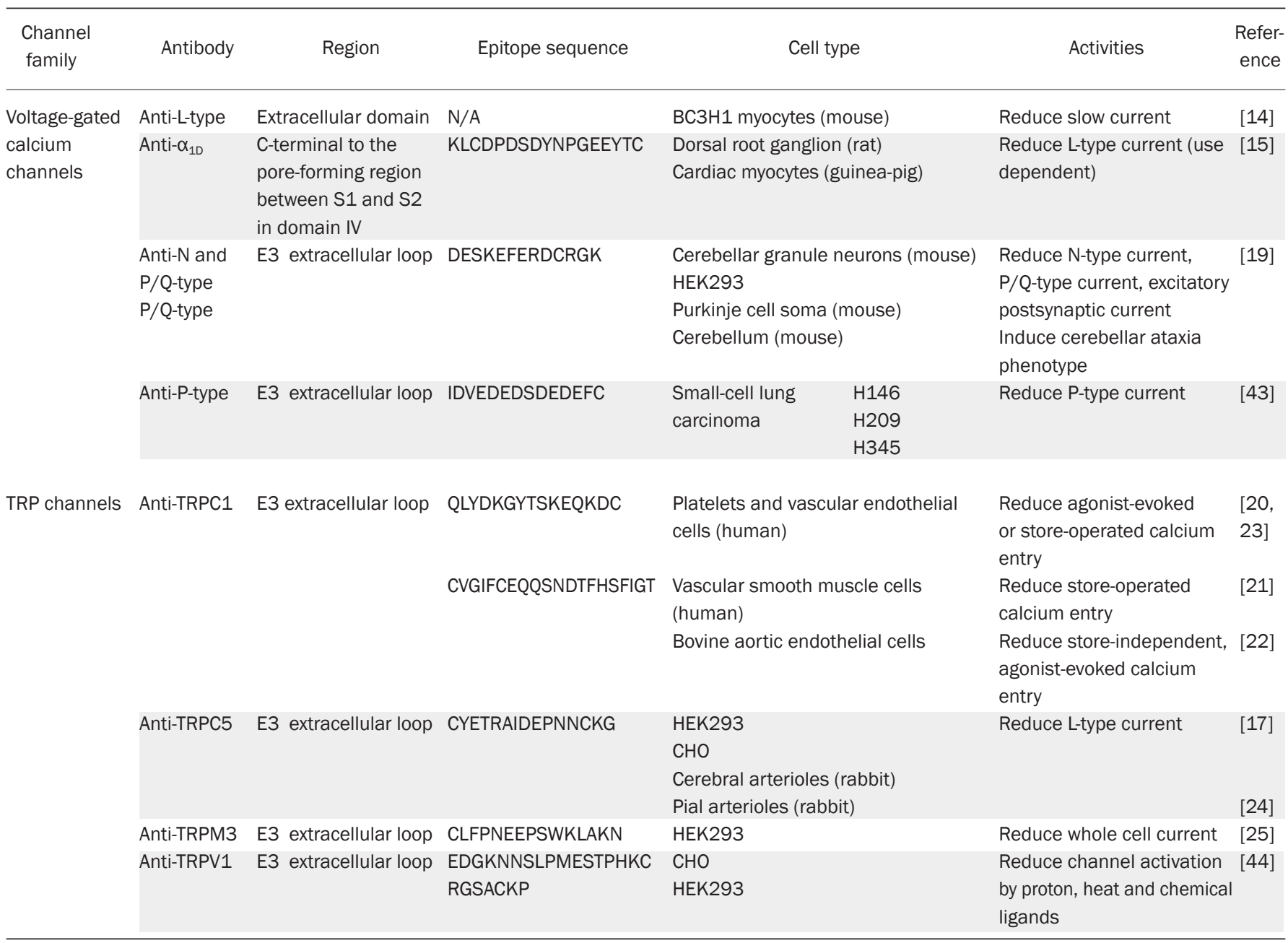

Physiol 1998; 111: 555-63.

17 Xu SZ, Zeng F, Lei M, Li J, Gao B, Xiong C, et al. Generation of functional ion-channel tools by E3 targeting. Nat Biotech 2005; 23 : 1289-93.

18 Alkire MT, Asher CD, Franciscus AM, Hahn EL. Thalamic microinfusion of antibody to a voltage-gated potassium channel restores consciousness during anesthesia. Anesthesiology 2009; 110: 766-73.

19 Liao YJ, Safa P, Chen YR, Sobel RA, Boyden ES, Tsien RW. Anti-Ca ${ }^{2+}$ channel antibody attenuates $\mathrm{Ca}^{2+}$ currents and mimics cerebellar ataxia in vivo. Proc Natl Acad Sci U S A 2008; 105: 2705-10.

20 Rosado JA, Brownlow SL, Sage SO. Endogenously expressed Trp1 is involved in store-mediated $\mathrm{Ca}^{2+}$ entry by conformational coupling in human platelets. J Biol Chem 2002; 277: 42157-63.

$21 \mathrm{Xu} \mathrm{SZ}$, Beech DJ. TrpC1 is a Membrane-spanning subunit of storeoperated $\mathrm{Ca}^{2+}$ channels in native vascular smooth muscle cells. Circ Res 2001; 88: 84-7.

22 Antoniotti S, Lovisolo D, Fiorio Pla A, Munaron L. Expression and functional role of bTRPC1 channels in native endothelial cells. FEBS Lett 2002; 510: 189-95.

23 Ahmmed GU, Mehta D, Vogel S, Holinstat M, Paria BC, Tiruppathi $\mathrm{C}$, et al. Protein kinase $\mathrm{C} \alpha$ phosphorylates the TRPC1 channel and regulates store-operated $\mathrm{Ca}^{2+}$ entry in endothelial cells. J Biol Chem 2004; 279: 20941-9.
24 Xu SZ, Boulay G, Flemming R, Beech DJ. E3-targeted anti-TRPC5 antibody inhibits store-operated calcium entry in freshly isolated pial arterioles. Am J Physiol Heart Circ Physiol 2006; 291: H2653-9.

25 Naylor J, Milligan CJ, Zeng F, Jones C, Beech DJ. Production of a specific extracellular inhibitor of TRPM3 channels. Br J Pharmacol 2008; 155: 567-73.

26 Tiwari-Woodruff S, Beltran-Parrazal L, Charles A, Keck T, Vu T, Bronstein J. $\mathrm{K}^{+}$channel KV3.1 associates with OSP/claudin-11 and regulates oligodendrocyte development. Am J Physiol Cell Physiol 2006; 291: C687-98.

27 Gómez-Varela D, Zwick-Wallasch E, Knötgen H, Sánchez A, Hettmann T, Ossipov D, et al. Monoclonal antibody blockade of the human Eag1 potassium channel function exerts antitumor activity. Cancer Res 2007; 67: 7343-9.

28 Agarwal J, Griesinger F, Stuhmer W, Pardo L. The potassium channel Ether a go-go is a novel prognostic factor with functional relevance in acute myeloid leukemia. Mol Cancer 2010; 9: 18.

29 Schwartz A, Palti Y, Meiri H. Structural and developmental differences between three types of $\mathrm{Na}$ channels in dorsal root ganglion cells of newborn rats. J Membr Biol 1990; 116: 117-28.

30 Sammar M, Spira G, Meiri H. Depolarization exposes the voltage sensor of the sodium channels to the extracellular region. J Membr Biol 1992; 125: 1-11. 
31 Chioni AM, Fraser SP, Pani F, Foran P, Wilkin GP, Diss JKJ, et al. A novel polyclonal antibody specific for the Nav1.5 voltage-gated $\mathrm{Na}^{+}$ channel 'neonatal' splice form. J Neurosci Methods 2005; 147: 8898.

32 Chan AC, Carter PJ. Therapeutic antibodies for autoimmunity and inflammation. Nat Rev Immunol 2010; 10: 301-16.

33 Scott AM, Wolchok JD, Old L. Antibody therapy of cancer. Nat Rev Cancer 2012; 12: 278-87.

34 Moskal JR, Kuo AG, Weiss C, Wood PL, O'Connor Hanson A, Kelso S, et al. GLYX-13: A monoclonal antibody-derived peptide that acts as an $\mathrm{N}$-methyl-D-aspartate receptor modulator. Neuropharmacology 2005; 49: $1077-87$.

35 Zhang XL, Sullivan JA, Moskal JR, Stanton PK. A NMDA receptor glycine site partial agonist, GLYX-13, simultaneously enhances LTP and reduces LTD at schaffer collateral-CA1 synapses in hippocampus. Neuropharmacology 2008; 55: 1238-50.

36 Burgdorf J, Zhang XL, Weiss C, Matthews E, Disterhoft JF, Stanton $\mathrm{PK}$, et al. The $\mathrm{N}$-methyl-D-aspartate receptor modulator GLYX-13 enhances learning and memory, in young adult and learning impaired aging rats. Neurobiol Aging 2011; 32: 698-706.

37 Pardridge WM, Boado RJ. Reengineering biopharmaceuticals for targeted delivery across the blood-brain barrier. Methods Enzymol 2012; 503: 269-92.
38 Atwal JK, Chen Y, Chiu C, Mortensen DL, Meilandt WJ, Liu Y, et al. A therapeutic antibody targeting BACE1 inhibits amyloid-beta production in vivo. Sci Transl Med 2011; 3: 84ra43.

39 Yu YJ, Zhang Y, Kenrick M, Hoyte K, Luk W, Lu Y, et al. Boosting brain uptake of a therapeutic antibody by reducing its affinity for a transcytosis target. Sci Transl Med 2011; 3: 84ra44.

40 Carter PJ. Potent antibody therapeutics by design. Nat Rev Immunol 2006; 6: 343-57.

41 Beck A, Wurch T, Bailly C, Corvaia N. Strategies and challenges for the next generation of therapeutic antibodies. Nat Rev Immunol 2010; 10: 345-52.

42 Meiri H. Detection of cell surface sodium channels by monoclonal antibodies - could the channels become exposed to the external surface and 'down regulated' by binding to antibodies? Brain Res 1986; 368: 188-92.

43 Barry E, Viglione M, Kim Y, Froehner S. Expression and antibody inhibition of P-type calcium channels in human small-cell lung carcinoma cells. J Neurosci 1995; 15: 274-83.

44 Klionsky L, Tamir R, Holzinger B, Bi X, Talvenheimo J, Kim H, et al. A polyclonal antibody to the prepore loop of transient receptor potential vanilloid type 1 blocks channel activation. J Pharmacol Exp Ther 2006; 319: 192-8. 